\title{
The Role of IT-Management in the Digital Transformation of Russian Companies
}

\author{
Volker Nissen \\ Professor, Department of Service Information Systems, volker.nissen@tu-ilmenau.de \\ Ilmenau University of Technology, Max-Planck-Ring 14, 98693 Ilmenau, Germany
}

Tatiana Lezina

Head, Chair of Information Systems in Economics, t.lezina@spbu.ru

Andrey Saltan

Assistant, Chair of Information Systems in Economics, a.saltan@spbu.ru

St. Petersburg State University, 7/9 Universitetskaya nab., 199034 St. Petersburg, Russia

\begin{abstract}
$\mathrm{N}$ owadays many business models rely heavily upon adequate IT management practices. Quite often in developed economies, the role of IT has organically evolved over decades from a mere business support function to an efficiency driver and enabler, and finally (at least in some cases) to a driver of business innovation and digital transformation. Unlike developed countries, little is known about the role of IT in companies of countries with transitional economies, such as Russia. Historical, political, and geographical reasons have in many areas of life led to
\end{abstract}

Abstract

\section{Keywords:}

information systems management; transition economies; role of IT; digital business transformation; case study research a "Russian way of doing things". Does this also hold true for IT management? By way of case study research, this contribution investigates the features of the IT-role and use in large Russian companies that are aware of the need for digital business transformation. The obtained results allow one to not only gain a better understanding of the situation in Russian companies through the prism of IT management practices but also to identify possible trends and challenges that appear relevant for organizations in other countries in economic transition or even in developed economies as well.
Citation: Nissen V., Lezina T., Saltan A. (2018) The Role of IT-Management in the Digital Transformation of Russian Companies. Foresight and STI Governance, vol. 12, no 3, pp. 53-61. DOI: 10.17323/25002597.2018.3.53.61 
I $\mathrm{n}$ a rapidly changing business world, information technology (IT) plays an essential role in the achievement of business objectives. Historically, IT management has focused on providing regular IT services as well as being involved in business processes efficiency improvement. Later, with further IT development and consolidation, it began to play a more significant role in new product development, the creation of new business models, and the discovery of new revenue sources [Hanschke, 2010]. At the same time, companies expect IT to contribute more measurable, direct, and flexible business processes [Johannsen, Goeken, 2006]. Increasingly, this requires IT to no longer be merely an "enabler" of business processes, but also to contribute to innovation in the technical side of the business. IT can, under certain conditions, act as a "strategic weapon" in the respective company's arsenal, that is, a source of competitive advantage [Byrd, Turner, 2001].

The importance of IT as a "strategic weapon" is especially relevant in the context of the transition to a digital economy, which is currently actively discussed by the Russian scientific and business communities. The digital economy, by implementing digital transformations, implies the transition of companies to a new technological environment. Still, until now there has been a lack of consensus among researchers and practitioners about what digital transformation means and which aspects of a company's management should oversee. Accordingly, there are multiple approaches ranging from a focus on technology, to digital customer engagement, to new digital business models, and so on.

The lack of clarity often results in piecemeal initiatives, missed opportunities, and false starts in business digitalization. From the organizations' point of view, digital transformation affects all aspects related to the company's architecture including business goals, business models, business processes, etc. [Bharadwa et al., 2013; Bhattacharya, Seddon, 2009]. The prime goal of digital transformation is to gain the benefits of information technologies and information systems, such as productivity improvements, and cost reductions. Nevertheless, to obtain these results, overall organizational commitment is required. However, this advantage is only possible if organizations have good business-IT-alignment (BITA). BITA can be defined as "the degree to which the IT mission, objectives, and plans support and are supported by the business mission, objectives, and plans" [Reich, Benbasat, 1996]. To obtain this alignment a company needs to have implemented an effective IT governance, which is "an actively designed set of IT governance mechanisms" that supports an "organization's mission, strategy, values, norms, and culture" [Weill, Ross, 2004]. On the other hand, "an important driving force to achieve business value through investments in IT" is a business-IT alignment defined as the fit and integration among business and IT strategies as well as business and IT structures [de Haes, van Grembergen, 2009]. The first area covered by this study concerns the strategic benefits brought by business-IT alignment and the second concerns the fact that IT managers consider business-IT alignment a vital issue [Leonard, Seddon, 2012]. In brief, this requires intense contacts and mutual interest and understanding on all management levels between business and IT departments. With the combination of technological know-how and a profound understanding of the business side of its company, the IT department can be critical in creating new and improved products and services, business processes, or business models. This crucial strategic issue has promoted the transition of IT from a mere support function to becoming a driver for business innovation [Kießling et al., 2010], which is required for the successful business digitalization.

While in the past a CIO was rarely part of the managing board, nowadays CIOs have frequently been promoted to the executive management [Holtschke et al., 2009]. While the continuous upward development of IT in western countries can be witnessed, the question arises, what the role, tasks, and perspectives of IT are in transition economies, such as Russia. A quick answer to this question, such as "Russia lags behind in this process by about 30 years", would ignore the particularities of the Russian political and economic past, as well as the enormous size of the country. Russian people often argue that they have a unique way of development that is different from international practice but can lead to great success [Prokhorov, 2002; Zhdanov, 2014].

Moreover, the Russian economy is still in transition as opposed to developed countries like Germany or the United States. The transitive state of the economy very often leads to significant heterogeneity, both from practices and principles of governance as well as the level of technological development. Some large companies are internationally competitive; however, many companies in Russia work in niche markets without much competition for historical, political, or geographical reasons. They often do not apply international standards in business and IT-management, but still operate successfully on their markets and may to join the global trend for digital transformation. Considering this particular situation, our research aims to achieve a better understanding of the particularities with respect to the role, tasks, and perspectives of IT at Russian companies facing digital business transformation. Unfortunately, today little is known about both the role of IT at companies in countries in transition and processes of their transformation. This research aims to help to close the existing research gap and analyze to what extent IT management practices in Russia differ from the world, what the key features and challenges are, and how consistent these practices are with the goal of digital business transformation. 


\section{Related Work}

Nowadays the topic of digital business transformation is widely discussed both in academic and business communities. This transformation can be defined as a change at different levels of business organizations that incorporates both the extensive usage of digital technologies to improve existing business processes and practices and the exploration of digital innovation to transform the overall business model. The observed discussion on the priority of the technological and business aspects of digital transformation attests to the necessity of an alignment between IT and business, specifically in the integration of ITstrategy and business strategy to achieve defined goals [Bharadwa et al., 2013; Kane et al., 2015; Urbach et al., 2017]. This discussion also reviews the basic understanding of the importance of this trend, but there is still need for clarification of the respective challenges and effects [Bley et al., 2016].

From an academic point of view, the role of IT at organizations has changed over time from "IT as a support function" to "IT as a driver for business innovation" [Kießling et al., 2010]. It represent the growing importance of IT for organizations and their ability to face more strategy-oriented challenges. Accordingly, the position of the IT-manager or CIO has changed fundamentally in developed countries over the last few years. Moreover, a company's ability to change increasingly depends upon its ability to change its IT or so-called "IT agility" [Nissen, von Rennenkampf, 2015]. High IT agility can contribute to increased business agility and thus create a competitive advantage.

Within this research, the focus is on companies' current attitude concerning the role of IT as well as the alignment of IT practices with the business model and objectives. The research is overall in line with existing studies for developed countries in the literature. In the United States, a series of studies [Luftman et al., 1999; Luftman, Derksen, 2012] longitudinally explored the role and tasks of IT as well as characteristics of the CIO. Following a similar approach, the study [Nissen, Termer, 2014] investigated the status quo in Germany. The results show a certain similarity, as could be expected with both, Germany and the US as fully developed countries.

Contrary to this, the existing studies on Russian experience and practice with IT management focus mostly on narrow aspects, such as the ability to withstand and quickly recover from disruptive incidents involving unplanned downtime and potential data losses [Ivanova, Lezina, 2014]. In summary, there is not much data on how the changing role and spheres of responsibility of IT are discussed in the literature for developed countries are accepted and implemented by IT management in Russia. One of the first broader attempts to assess the role and functions of IT departments in Russian companies was undertaken in [Lezina et al., 2016]. The authors conclude that today the role of IT at many Russian companies is at best an enabler, often just an instrument to increase efficiency, and in a sizeable number of cases, it still only is a support function. In particular, there is a marked lack of viewing IT as a driver of innovation. The current contribution builds and expands upon these initial results.

\section{Research Methodology}

The conducted research addresses the use of information systems and technologies in implementing digital business transformation. Following the recommendations on examining complex and interdisciplinary phenomena linked to managerial perception, roles, and complex interaction patterns of IT management, case study research is one of the widely acknowledged qualitative research methods and seemed appropriate for the purpose of our study [Paré, 2004].

To develop a better understanding of IT-management practices at Russian companies and their role in digital business transformation, research questions were posed:

RQ1: What is the role of IT management in implementing digital business transformation and how do existing practices correspond with international ones?

RQ2: What are the major factors constraining digital business transformation practices, objectives, and strategies?

The research questions call for an exploratory research approach, considering the lack of prior investigations into these areas. Thus, a positivistic, exploratory multiple case study wasconducted. The case sampling strategy was guided by a diverse case approach. However, all companies are profitable and consider digital transformation an essential step in their immediate further development. We deliberately did not include companies directly related to the IT sector, since we were more interested in cases of companies for which IT is not a core business, but could be a valuable "strategic weapon". Companies were selected for analysis based upon differences in size, maturity level, and industry. A general overview of the selected organizations is presented in Table 1.

For the study, a series of semi-structured interviews with CIO, IT managers, and executives (at least two persons per company) from four companies were carried out. During the interviews, the following topics were addressed: general information about the company (name, industry, the number of employees, hierarchal structure, market share, etc.), vision towards digitalization (digitalization trends in their industry, strategic goals for their company, etc.), IT management practices, and their role in digital transformation (CIO role, IT department structure, IT strategy, policies). 
Table 1. Characteristics of Organizations in the Case Study

\begin{tabular}{|l|c|c|c|c|c|}
\hline Case & A & B & C & D & E \\
\hline Industry & Oil and Gas & Clothing & Bakery & Banking & Machinery \\
\hline Number of employees & $>70,000$ & $>15,000$ & $>2,500$ & $>15,000$ & $>3,000$ \\
\hline Geographical presence & Global & $\begin{array}{c}\text { Russia, China, CIS } \\
\text { countries }\end{array}$ & Russia (3 regions) & Russia & Russia \\
\hline Interview partners & $\begin{array}{c}\text { IT manager, Head } \\
\text { of Business Analysis } \\
\text { Department }\end{array}$ & $\begin{array}{c}\text { Vice CIO, Head of } \\
\text { Business Analysis } \\
\text { Department }\end{array}$ & $\begin{array}{c}\text { Senior IT manager, } \\
\text { Head of Business } \\
\text { Analysis Department }\end{array}$ & Senior IT manager & $\begin{array}{c}\text { Senior Project } \\
\text { Manager }\end{array}$ \\
\hline Source: compiled by the authors.
\end{tabular}

\section{Case Study Analysis}

Each case is analyzed on an individual basis initially based on information gathered during the interviews as is useful for exploratory case research.

\section{Case A}

This company is one of the largest Russian oil and gas companies operating in 150 countries. It is part of a holding, but it has a significant level of autonomy in its management. The parent company involves itself only at the level of strategy development and annual monitoring of its implementation.

The company management has a high level of understanding of the importance of IT. However, while digital transformation as the future of their core business is undisputed, the exact goals of such a transformation remain to be clarified. Entering the digital world is not seen as an issue of competition, but a chance to find new business opportunities, new markets, and new business models. The company has enough resources to implement this transformation, but still, the ultimate goal is not entirely clear.

In the corporate hierarchy, the IT department is subordinated to the CFO. This reflects the importance of the financial performance of IT. In general, IT operates according to a traditional decision-making scheme that requires a large number of approvals, especially when it comes to projects related to performing changes in the accounting system, automation of production, and support of business processes. However, recently the department of business analysis was allocated to a separate structural unit, and this unit has more flexibility in decision-making and project implementation. Strategically, the digital business transformation is assigned to this unit, and the unit is in charge of making propositions regarding required changes in methodology, practices, and IT-systems. Currently, the company is implementing a BI-system.

The company is the leader in its industry in successfully implementing internal projects related to digital business transformation. While transformation management does understand that data science and advanced analytics procedures should not be performed purely by IT staff, but that all business units should have access to "raw" data and be able to analyze it. Company management believes that IT should become even more decentralized, and all business units should have "mini IT" departments.

\section{Case B}

Company B specializes in the production and sale of casual clothes and sportswear as well as fitness equipment. The company's subdivisions are located in Russia, CIS countries, and China. Strategic KPIs include operational efficiency, market share, geographical presence, and profit margin. The company operates in a highly competitive environment: its main competitors are both local ventures and global enterprises with internationally known brands. The executive management of the company considers the purpose and essence of digital business transformation the only way to preserve and increase its market share in a highly competitive environment.

The IT department has a centralized structure with the CIO reporting to the CEO. Company management declares that IT has a strategic role in the company with IT managers actively involved in business analysis and development. Business profitability and performance, as well as innovative business development, are named as the principal objectives of IT. The company has a long-term IT development strategy created by the IT department in conjunction with other stakeholders and approved by the Board of Directors. However, quite often, additional IT-related projects are initiated by the company's executive management, and IT is involved only at the stage of discussing issues of implementation. The evaluation of IT performance and IT-related projects is performed in joint meetings with key internal stakeholders and based on non-formalized opinions of different business units.

The company has a portfolio of successful IT projects related to production and logistics. The company already considers itself unique regarding the level of IT use among companies in the same industry in Russia. Management believes they can replicate the success of Amazon on a smaller scale on local Russian markets. 
Following the trends in the competitive environment and facing certain challenges related to personnel qualification, the company increasingly sees the potential of IT as a cure-all and tries to increase business efficiency by minimizing the human factor in decision-making processes (for example, in stock planning). The company is more willing to invest not in the development of digital competencies of employees, but in IT. However, practice shows that this strategy has many side effects: ignoring professional expertise in making management decisions can inflict significant damage to the company in future.

\section{Case C}

Company $\mathrm{C}$ belongs to the food industry, having its offices across Russia including Moscow, St. Petersburg, and the Volga region. Management KPIs include market share, revenue, and amount of goods sold. The company operates in a highly competitive environment. The management considers brand awareness, customer focus and technological innovations as their prime competitive advantages. At present, the company considers digitally transforming parts logistics and production.

The IT department reports to the CFO and is divided into two units: a technical unit that maintains functional operation of the equipment and a software development unit. The principal role of IT in the company is to support current business processes and promote business innovations. The primary objective is to facilitate efficient production cycles, promote sales, and support other business processes. There is no IT strategy at the company. The decision-making process for the implementation and purchase of new IT solutions is most often based on the needs of the business or for a planned replacement of existing IT solutions. The core characteristic that determines the choice of particular IT solutions is their reliability. The company automated part of the production and also uses IT-functionality associated with logistics. As consumer behavior changes, the company aims to improve their IT solution, particularly in logistics to meet changing market requirements. Company $\mathrm{C}$ considers itself as an industry leader regarding IT practices.

Company C plans to implement smart contracts based on Blockchain technology. At the same time, the principal motivation for the project is reducing the price for the consumer. The company overemphasizes the technological superiority of the project and does not consider the possibility that the new technology may not be accepted by consumers, especially on the B2B market.

\section{Case D}

Company D is one of the leading Russian banks. Being a joint stock company, it is traded on Russian and foreign stock exchanges, the state is the controlling shareholder of the bank. Recently, the process of merging with several regional banks was completed and the principal difficulty was the unification of heterogeneous information systems into the group's independent banking system. Now the bank is actively involved in the process of digital transformation, following the government's policy of the digitalization of the economy.

Despite the wave of mergers and acquisitions over the past few years and the increasing share of banks with significant state ownership, the banking sector remains highly competitive, especially in the B2C segment. All critical innovations in the banking sector are associated with new technologies and overall digitalization. Fully understanding these trends, Company D's top managers state that they have a clear vision of IT and information systems both as a strategic weapons and instruments of tactical efficiency improvement. The company has enough resources to implement digital transformation but tends to overestimate the potential of advanced technologies.

Moreover, for the sake of implementing new and innovative digital projects, senior managers do not appreciate the feedback from middle managers, which can drastically reduce the effectiveness of these projects.

\section{Case E}

Company $\mathrm{E}$ is a manufacturing company that produces high-tech devices and equipment for various industries.

The IT department is separated and not involved in the process of managerial decision-making. At the same time, the IT department has a sufficient budget to purchase and develop new IT and IS solutions.

Company E has an understanding of the need and the desire to update production capacities and maybe even implement the overall digital transformation of its business, however, most initiatives in this direction cannot be implemented due to the moral backlog of the regulatory framework governing the activities of companies fulfilling government orders and operating in the military-industrial complex. The key driver for digital transformation is the opportunity to increase efficiency and accelerate business processes related to the design, development, and the launch of commercial production of new technological products.

Company E lacks explicit and formalized criteria for evaluating the activities of the IT department and the efficiency of IT projects. Most often, decisions about new projects are made as a result of the negotiation process between the company's top-managers and the IT department. The initiators of the 
Table 2. Results of Cross-Case Analysis

\begin{tabular}{|c|c|c|c|c|c|}
\hline Case & A & B & $\mathrm{C}$ & D & $\mathbf{E}$ \\
\hline Role of IT & - Business innovator & - Enabler & - Support function & $\begin{array}{l}\text { - Business } \\
\text { innovator }\end{array}$ & $\begin{array}{l}\text { - Support } \\
\text { function }\end{array}$ \\
\hline $\begin{array}{l}\text { Organizational } \\
\text { integration of } \\
\text { IT in corporate } \\
\text { structure and IT's } \\
\text { role in strategic } \\
\text { decision-making }\end{array}$ & $\begin{array}{l}\text { - Decentralized } \\
\text { - Subordinated to the CFO } \\
\text { - IT department's } \\
\text { perspective is taken into } \\
\text { account when discussing } \\
\text { ways to implement } \\
\text { strategic objectives } \\
\text { - IT can initiate projects } \\
\text { themselves; however, the } \\
\text { reconciliation process is } \\
\text { highly bureaucratized }\end{array}$ & $\begin{array}{l}\text { - Centralized } \\
\text { - Subordinated to the } \\
\text { CEO } \\
\text { - IT is actively } \\
\text { involved in business } \\
\text { development and } \\
\text { decision-making on } \\
\text { IT-related project } \\
\text { implementation }\end{array}$ & $\begin{array}{l}\text { - Centralized } \\
\text { - Subordinated to } \\
\text { the CFO } \\
\text { - Level of } \\
\text { involvement in } \\
\text { strategic decision- } \\
\text { making is low } \\
\text { - IT has sufficient } \\
\text { flexibility only in } \\
\text { implementation of } \\
\text { projects }\end{array}$ & $\begin{array}{l}\text { - Centralized } \\
\text { - IT department's } \\
\text { perspective } \\
\text { is taken into } \\
\text { account while } \\
\text { discussing ways } \\
\text { to implement } \\
\text { strategic } \\
\text { objectives }\end{array}$ & - Centralized \\
\hline $\begin{array}{l}\text { Objectives } \\
\text { of IT-related } \\
\text { projects aimed at } \\
\text { digital business } \\
\text { transformation }\end{array}$ & $\begin{array}{l}\text { - Market share retention } \\
\text { in a situation of market } \\
\text { saturation } \\
\text { - New business } \\
\text { opportunities } \\
\text { - Business process } \\
\text { improvement } \\
\text { - Quality and transparency } \\
\text { of management decisions } \\
\text { - Labor cost reduction }\end{array}$ & $\begin{array}{l}\text { - Market share retention } \\
\text { in a situation of market } \\
\text { saturation } \\
\text { - The desire to follow the } \\
\text { digital business leaders } \\
\text { - Business diversification } \\
\text { and development }\end{array}$ & $\begin{array}{l}\text { - Market share } \\
\text { retention in a } \\
\text { situation of market } \\
\text { saturation } \\
\text { - Improving financial } \\
\text { performance } \\
\text { - Operational cost } \\
\text { reduction }\end{array}$ & $\begin{array}{l}\text { - Market share } \\
\text { retention in } \\
\text { a situation of } \\
\text { market saturation } \\
\text { - The desire to } \\
\text { follow the digital } \\
\text { business leaders } \\
\text { - Following } \\
\text { political policy } \\
\text { on digital } \\
\text { business } \\
\text { transformation } \\
\end{array}$ & $\begin{array}{l}\text { - Market share } \\
\text { retention in } \\
\text { a situation } \\
\text { of market } \\
\text { saturation } \\
\text { - The desire } \\
\text { to follow } \\
\text { the digital } \\
\text { business } \\
\text { leaders }\end{array}$ \\
\hline $\begin{array}{l}\text { Key performance } \\
\text { indicators of } \\
\text { IT effectiveness } \\
\text { and associated } \\
\text { assessment of IT } \\
\text { practices }\end{array}$ & $\begin{array}{l}\text { - KPIs and assessment } \\
\text { procedures are not } \\
\text { formalized, informal } \\
\text { assessment is based on } \\
\text { financial performance }\end{array}$ & $\begin{array}{l}\text { - KPIs and assessment } \\
\text { procedures are not } \\
\text { formalized, informal } \\
\text { assessment is based on } \\
\text { financial performance }\end{array}$ & $\begin{array}{l}\text { - KPIs and } \\
\text { assessment } \\
\text { procedures are } \\
\text { not formalized, } \\
\text { informal } \\
\text { assessment usually } \\
\text { based on technical } \\
\text { indicators (number } \\
\text { of incidents, } \\
\text { number of failures, } \\
\text { etc.) }\end{array}$ & $\begin{array}{l}\text { - KPIs and } \\
\text { assessment } \\
\text { procedures are } \\
\text { formalized }\end{array}$ & $\begin{array}{l}\text { - KPIs and } \\
\text { assessment } \\
\text { procedures } \\
\text { are not } \\
\text { formalized, } \\
\text { informal } \\
\text { assessment } \\
\text { is based on } \\
\text { financial } \\
\text { performance }\end{array}$ \\
\hline $\begin{array}{l}\text { Key challenges } \\
\text { facing the } \\
\text { implementation of } \\
\text { IT-related projects } \\
\text { and the continued } \\
\text { improvement of } \\
\text { IT management } \\
\text { practices }\end{array}$ & $\begin{array}{l}\text { - Lack of qualified } \\
\text { personnel } \\
\text { - Personnel non- } \\
\text { acceptance }\end{array}$ & $\begin{array}{l}\text { - Lack of qualified } \\
\text { personnel } \\
\text { - Inefficient business } \\
\text { processes at the } \\
\text { company } \\
\text { - Large number of } \\
\text { heterogeneous, } \\
\text { often non-integrated } \\
\text { information systems }\end{array}$ & $\begin{array}{l}\text { - Lack of qualified } \\
\text { personnel } \\
\text { - High cost of IT } \\
\text { solutions } \\
\text { - Short planning } \\
\text { horizon }\end{array}$ & $\begin{array}{l}\text { - Lack of qualified } \\
\text { personnel } \\
\text { - Large number } \\
\text { of hetero- } \\
\text { geneous, often } \\
\text { non-integrated } \\
\text { information } \\
\text { systems }\end{array}$ & $\begin{array}{l}- \text { Lack of } \\
\text { regulation } \\
\text { - Lack of } \\
\text { qualified } \\
\text { personnel }\end{array}$ \\
\hline
\end{tabular}

projects are middle-level managers from various departments. In general, IT operates according to a traditional decision-making process that requires a large number of approvals.

The consolidation of the analysis of individual cases along with a cross-case analysis facilitates a deeper understanding of the cases and accentuates the differences between them. To illustrate specific characteristics of the different IT roles and management practices, Table 2 provides a comparison of these five cases.

\section{Discussion}

Our findings allowed us to answer our questions regarding role of IT in the implementation digital business transformation at Russian companies.

RQ1: What is the role of IT management in implementing digital business transformation and how do existing practices correspond with international ones?

All interviewees claimed that, at their companies, IT is considered a critical driver for the development of their companies in the age of the digital economy. However, as the example of Company C demonstrates, the reality is slightly different. It might be difficult to assess the extent to which this attitude of topmanagers and board members in developing and transition countries, including Russia, is founded upon a real understanding of the requirements and challenges of a truly digital business transformation. Alternatively, managers are perhaps just following the "fashionable" approach extensively discussed these days by the global business community. Moreover, Russia is characterized by a predisposition to follow the fashion for new technologies and practices. This often leads to the fact that companies are not critical enough about the choice of IT solutions regarding their effectiveness and appropriateness. The companies' 
top managers believe that the very fact of digitization creates a positive image and enhances the market value and importance of the company.

In the 2000s, the role of the IT department at the majority of Russian companies was limited simply to providing IT support. The owners and top managers did not see any reason to invest in IT even when without proper IT infrastructure and support, the customer base grew by $10-15 \%$ per month and with revenue and sales up by $20 \%$. The CIO / IT director was not involved in the decision-making process, and he or she was rarely a member of the board of directors. Certainly, specific IT projects were implemented, but this was done without a systematic analysis of the importance and proper economic justification.

Nowadays the situation has changed. The interviews showed that companies and organizations in Russia, especially those who have ambitious goals and the necessary resources, want to find a leap-frog solution to jump forward and overcome current problems. Nowadays, especially in Russia, digitalization and IT are considered contributors to such solutions and processes. At the same time, many companies believe that digital transformation can be implemented through the implementation of new IT without the sufficient transformation of business processes, business models, and data management practices. At these companies, despite the often large budgets for developing, purchasing, and implementing new information systems and technologies, IT remains a supporting business function rather than a driver of company development (cases $\mathrm{C}$ and $\mathrm{E}$ ). However, an alternative vision also exists, and some companies are exploring successful practices of digital transformation at domestic and foreign companies and follow the recommendations of leading analytical agencies and consulting companies (cases A and D). As a rule, these are the companies that do not have any restrictions in financing their projects and they are companies that have experience with international cooperation.

In Russia, the process of integrating the function of IT and business is lengthy. As a result, managers do not have a deep understanding of digital transformation, they only perceive it from a technological point of view and set tasks for IT managers without giving them the opportunity to influence the management processes in general.

RQ2: What are the major factors constraining digital business transformation practices, objectives, and strategies?

The first essential factor that can be considered a potential risk is the lack of rationality in conducting a cost-benefit analysis and assessment of various IT-related projects. Top-down pressure provokes an overestimation of results and an underestimation of costs. Companies in Russia, like many other transition economies, have a short planning horizon. They are not much concerned about the long-term consequences of current projects, especially if they promise significant short-term achievements. During the interviews, we figured out that none of the companies do, in fact, have metrics for assessing the effectiveness and efficiency of IT as well as any formalized assessment procedures. As a result, given the necessary resources, IT-related projects and changes in practices are quickly initiated and terminated in more or less an ad-hoc manner when new, more "advanced" technologies, practices or approaches seem to appear.

Even though all companies for research were selected from among those who position themselves as active participants in the process of digital transformation, even among them, there is a severe gap in the financial opportunities for implementing projects. There are leading companies, often with a large state participation, which has unlimited development budgets. These companies want to overcome the backlog of Western partners and competitors due to large-scale digital transformation. This approach, often called the "Russian way" by the companies themselves, does allow for achieving certain outcomes, but the economic feasibility may remain questionable. The rest of the companies are lagging behind, they do not fully understand the concept of digital transformation and do not have the necessary budgets. Leading companies have the opportunity to work by "trial and error", but for companies with smaller budgets and capabilities, verified practices are needed.

The third limitation of the observed status quo is a too technology-minded attitude concerning ITrelated projects and changes. Most of the companies participating in our case study wish to follow the international leaders from Europe and North America. Consequently, they try to apply the best available technologies supplemented with successful business practices. However, quite often the business units, production facilities, and organizational processes have a poor performance record and are not ready for the expected technological breakthrough. Moreover, all respondents mentioned a lack of specialists with the necessary qualifications. Business informatics education in Russia significantly lags behind Germany and until now, the universities are unable to meet the market demand for qualified IT specialists. This situation occurs partly because business informatics programs intended to address this shortage were first launched only in 2003 [Ivanova et al., 2015].

Among the industries, the most significant achievements in the area of digital transformation are observed at companies from the service industries. In many respects, this can be explained by the smaller scale of production processes, greater customer orientation, and fewer necessary investments.

Finally, the top-down approach often results in IT-implementations or transformation practices where there is almost no focus on usability and user's acceptance. However, when the relevant stakeholders 
do not accept business processes, they will tend to circumvent them or not even trigger these processes (or not use the associated IT-systems) at all [Lezina et al., 2016]. In addition to the factors mentioned above, this creates an increased risk to the success of IT-related projects. In summary, the current status of IT management practices in Russia provides companies with the opportunity to achieve a significant breakthrough in the short term; however, the sustainability of the results, in the long run, may be called into question especially in case of resource scarcity.

\section{Conclusions and Limitations}

Russia is an extremely heterogeneous country, with its historical and political particularities that are further exponentiated by the enormous size of its territory. In many respects, through the example of Russia, we see the development of management practices within companies that takes place in other countries with developing and transitioning economies. When we speak about the option of a "Russian way", it is necessary to account for the resource-rich structure of the economy and the heterogeneity of economic development regarding economic complexity and coherence. In particular, the idea of a Russian way of economic development and special management models is often found in the introduction of innovations, the transition to a knowledge economy, and knowledge society [Kulikov, 2016; Michailova, 2000; Ponomarev, Dezhina, 2016]. In general, the Russian way is often associated with effectiveness through inefficiency, and this research has proven that this logic is present when it comes to IT management. This IT and business management model on the basis of hierarchy and a focus on operations as well as the significant impact of the human factor can deliver noticeable results regarding digital business transformation in the short-term; however, the sustainability of the achieved results may be questionable.

This study may have certain limitations worth mentioning here. First, the responses from the five companies in the form of in-depth interviews could not be considered a significant amount of information for analysis, and this qualitative study provides perspectives on the role of IT in digital business transformation and IT-management practices. Second, the research possesses an exploratory nature and does not provide evident managerial insights. In order to enhance the validity of this case study's findings and improve the applicability and practical contributions of the study, future studies could include a broader case sample that would allow one to obtain more reliable insights. This could be supplemented with a design-based approach to support the evalucation of IT management practices to support digital business transformation.

We would like to express our gratitude to the DAAD (German Academic exchange service) for financial support in the framework of the project «Partnership with Eastern Universities».

\section{References}

Bharadwa A., Sawy O.A., Pavlou P.A., Venkatraman N. (2013) Digital business strategy: Toward a next generation of insights. MIS Quarterly, vol. 37, no 2, pp. 471-482.

Bhattacharya P.J., Seddon P.B. (2009) Role of Enterprise Systems in Business Transformations: A Management Perspective. Proceedings of the 20th Australasian Conference on Information Systems, 2-4 December 2009, Melbourne, Sydney: Australasian Association for Information Systems (AAIS), pp. 278-289.

Bley K., Leyh C., Schäffer T. (2016) Digitization of German Enterprises in the Production Sector - Do they know how 'digitized' they are?, Proceedings of the 22nd Americas Conference on Information Systems (AMCIS 2016), August 11-04, San Diego - California, USA, Atlanta, GA: Association for Information Systems (AIS), pp. 1-10.

Byrd T.A., Turner D.E. (2001) An exploratory analysis of the value of the skills of IT personnel: Their relationship to IS infrastructure and competitive advantage. Decision Sciences, vol. 32, no 1, pp. 21-47.

de Haes S., van Grembergen W. (2009) An Exploratory Study into IT Governance Implementations and its Impact on Business/IT Alignment. Information Systems Management, vol. 26, no 2, pp. 123-137.

Hanschke I. (2010) Strategic IT Management: A Toolkit for Enterprise Architecture Management, Berlin; Heidelberg: Springer-Verlag.

Holtschke B., Hauke H., Hummel T. (2009) Innovationen als Herausforderung. Quo Vadis CIO? (eds. B. Holtschke, H. Hauke, T. Hummel), Berlin; Heidelberg: Springer-Verlag, pp. 31-44.

Ivanova V., Kazakova E., Lezina T., Martyanova V., Saltan A., Siebenkäs A., Stelzer D. (2015) Comparing Bachelor Studies in Business Informatics at Universities in Russia and Germany. RUDN Journal of Informatization in Education, no 4, pp. 123-140.

Ivanova T., Lezina T. (2014) Evolutsiya biznes-informatiki kak nauki [Evolution of Business Informatics as a Science: The European, American and Russian Perspective]. Ekonomika i Upravlenie [Economics and Management], no 2 (100), pp. 44-50 (in Russian). 
Johannsen W., Goeken M. (2006) IT-Governance - neue Aufgaben des IT-Managements. HMD -Praxis Der Wirtschaftsinformatik, issue 250, pp. 7-20.

Kane G.C., Palmer D., Philips Nguyen A., Kiron D., Buckley N. (2015) Strategy, Not Technology, Drives Digital Transformation. Becoming a Digitally Mature Enterprise, Cambridge, MA: MIT Sloan Management School; Deloitte.

Kießling M., Wilke H., Kolbe L.M. (2010) Overcoming challenges for managing IT innovations in non-IT companies. Proceedings of the 16th Americas Conference on Information Systems (AMCIS 2010), August 12-15, 2010, Lima, Peru, Atlanta, GA: Association for Information Systems (AIS), pp. 1-9.

Kulikov S.B. (2016) Russian way to the knowledge-based society. Foresight, vol. 18, no 4, pp. 379-390.

Leonard J., Seddon P. (2012) A Meta-model of Alignment. Communications of the Association for Information Systems, vol. 31, no 11, pp. 231-259.

Lezina T., Nissen V., Reimer K., Saltan A. (2016) The Role and Tasks of IT in Russian Companies - A Survey of the Status Quo. Proceedings of the GSOM Emerging Markets Conference, Saint Petersburg: Saint-Petersburg University, pp. 232-234.

Luftman J., Derksen B. (2012) Key Issues for IT Executives 2012: Doing More with Less. MIS Quarterly Executive, vol. 11, no 4, pp. 207-218.

Luftman J., Papp R., Brier T. (1999) Enablers and inhibitors of business-IT alignment. Communications of the Association for Information Systems (AIS), vol. 1, article 11, pp. 1-33. Available at: https://pdfs.semanticscholar.org 19dc6/0273c9651a378d4463e038a2d33e5cf6d3b7.pdf, accessed 28.03.2018.

Michailova S. (2000) Contrasts in culture: Russian and Western perspectives on organizational change. Academy of Management Perspectives, vol. 14, no 4, pp. 99-112.

Nissen V., von Rennenkampf A. (2015) Measuring and managing IT agility as a strategic resource - examining the IT application systems landscape. Journal of Applied Informatics, vol. 10, no 6, pp. 5-30.

Nissen V., Termer F. (2014) Business - IT-Alignment: Ergebnisse einer Befragung von IT-Führungskräften in Deutschland. HMD - Praxis Der Wirtschaftsinformatik, vol. 51, no 5, pp. 549-560.

Paré G. (2004) Investigating Information Systems with Positivist Case Study Research. Communications of the Association for Information Systems (AIS), vol. 13, no 1, pp. 233-264.

Ponomarev A., Dezhina I. (2016) Approaches to the Formulation of Russia's Technological Priorities. Foresight and STI Governance, vol. 10, no 1, pp. 7-15.

Prokhorov A. (2002) Russkaya model'upravleniya [Russian Management Model], Moscow: CJSC “Zhurnal Ekspert” (in Russian).

Reich B.H., Benbasat I. (1996) Measuring the Linkage between Business and Information Technology Objectives. MIS Quarterly, vol. 20, no 1, pp. 55-81.

Urbach N., Drews P., Ross J.W. (2017) Digital Business Transformation and the Changing Role of the IT Function. MIS Quarterly Executive, vol. 16, no 2, pp. 1-4.

Weill P., Ross J.W. (2004) IT Governance: How Top Performers Manage IT Decisions Rights for Superior Results, Cambridge, MA: Harvard Business School Press.

Zhdanov D. (2014) The Russian Management Model: Between Yesterday and Tomorrow. Upravlenets, no 6 (52), pp. 40-48 (in Russian). 